\title{
ANALISIS DIMENSI KUALITASTERHADAP KEPUTUSAN PEMBELIAN HANDPHONE MEREK NOKIAPADA SENTRAL PHONE SAMARINDA
}

\author{
SUYANTO \\ Lecturer at the Faculty of Economics, Management Department, UWGM Samarinda \\ yanto77paseer@gmail.com
}

\begin{abstract}
Based on the discussion of the results of the research and hypothesis testing with the F test (simultaneous test) it is known that the quality dimension variable has a significant effect on the purchase decision variable because $\mathrm{F}$ count> Ftable $(6,278>2,143)$, thus the proposed hypothesis is acceptable. Based on the calculation of the coefficient of determination R2 the influence of the independent variables on the dependent variable is $43.4 \%$. Furthermore, based on the test (partial test) it is known that there are three independent variables that have a significant effect on the dependent variable, namely variable conformance, endurance, and aesthetics. Key word: Quality Dimension, Purchasing Decision
\end{abstract}

\section{ANALISIS DIMENSI KUALITAS TERHADAP KEPUTUSAN PEMBELIAN HANDPHONE MEREK NOKIA PADA SENTRAL PHONE SAMARINDA}

\author{
SUYANTO \\ ${ }^{1}$ Dosen Fakultas Ekonomi Jurusan Manajemen UWGM Samarinda \\ yanto77paseer@gmail.com
}

\begin{abstract}
ABSTRAK
Berdasarkan pembahasan hasil penelitian dan pengujian hipotesis dengan uji $\mathrm{F}$ (uji serentak) diketahui bahwa variabel dimensi kualitas berpengaruh signifikan terhadap variabel keputusan pembelian karena $F_{\text {hitung }}>F_{\text {tabel }}(6,278>2,143)$, dengan demikian hipotesis yang diajukan dapat diterima. Berdasarkan perhitungan koefisien determinasi $\mathrm{R}^{2}$ kuatnya pengaruh variabel independen terhadap variabel dependen adalah sebesar 43,4\%. Selanjutnya berdasarkan uji $\mathrm{t}$ (uji parsial) diketahui bahwa ada tiga variabel independen yang berpengaruh secara signifikan terhadap variabel dependen yaitu variabel konformansi, daya tahan, dan estetika.

Key word: Dimensi Kualitas, Keputusan Pembelian
\end{abstract}




\section{PENDAHULUAN \\ Latar Belakang}

Perkembangan teknologi telekomunikasi khususnya handphone yang cukup pesat di dunia baik di Asia maupun di Eropa, yang mana dampaknya juga dapat dirasakan di Indonesia. Banyak merek handphone yang cukup terkenal seperti Nokia, Sony Ericsson, Samsung, LG, Black Berry, Motorola, Mito, Nexian, dan masih banyak lagi merek lain yang ikut serta meramaikan penjualan handphone di Indonesia dan khususnya di Samarinda.

Walaupun banyak merek handphone yang cukup terkenal, tetapi hingga saat ini handphone merek Nokia tetap menjadi produk yang sangat diminati para konsumen. Hal tersebut menyebabkan banyak perusahaan distributor yang menjual handphone merek Nokia dengan tujuan untuk meningkatkan volume penjualan maupun omzet penjualan perusahaan. Handphone merek Nokia bukan saja diminati para konsumen karena merek yang terkenal, tetapi juga karena fitur, daya tahan, desain, dan kemudahan mendapatkan suku cadang, serta banyak hal-hal lain yang membuat handphone-handphone merek Nokia masih tetap diminati para konsumen hingga saat ini, walaupun sebenarnya banyak handphone merek lain yang bermunculan bahkan dengan harga yang jauh lebih murah.

\section{Rumusan Masalah}

“Apakah dimensi kualitas berpengaruh terhadap keputusan pembelian handphone merek Nokia pada Sentral Phone Samarinda?

\section{METODOLOGI PENELITIAN}

\section{Metode Penelitian}

Penelitian deskriptif sendiri adalah penelitian dengan melakukan survei secara langsung ke objek penelitian, dan kemudian melakukan analisa dan menginterprestasikan pengaruh variabel performa $\left(\mathrm{X}_{1.1}\right)$, keistimewaan $\left(\mathrm{X}_{1.2}\right)$, keandalan $\left(\mathrm{X}_{1.3}\right)$, konformansi $\left(\mathrm{X}_{1.4}\right)$, daya tahan $\left(\mathrm{X}_{1.5}\right)$, estetika $\left(\mathrm{X}_{1.6}\right)$, kualitas yang dipersepsikan $\left(\mathrm{X}_{1.7}\right)$, kemampuan pelayanan $\left(\mathrm{X}_{1.8}\right)$ terhadap keputusan pembelian (Y).

Populasi dalam penelitian ini adalah jumlah konsumen yang membeli handphone merek Nokia pada Sentral Phone Samarinda pada bulan Juni tahun 2016, yaitu sebanyak 126 konsumen.

Sampel ditentukan dengan menggunakan rumus Slovin sebagai berikut: adalah sebagai berikut :

$$
\text { " } \mathrm{n}=\frac{\mathrm{N}}{1+\mathrm{Ne}^{2}}
$$

Keterangan : $\quad \mathrm{n}$ : Ukuran Sampel

N : Ukuran Pupulasi 
e : Persentase karena ketidaktelitian karena kesalahan pengambilan sampel yang masih dapat diinginkan. "1

Berdasarkan rumus di atas maka perhitungan sampel dalam tulisan ini dengan persentase ketidaktelitian $10 \%$, dapat dilihat sebagai berikut :

$$
\begin{aligned}
\mathrm{n}=\frac{\mathrm{N}}{1+\mathrm{Ne}^{2}} & =\frac{126}{1+126(0,1)^{2}}=\frac{126}{1+126(0,01)} \\
& =\frac{126}{1+1,26}=\frac{126}{2,26} \\
& =55,7 \\
& =56
\end{aligned}
$$

Jadi : jumlah sampel dalam penelitian ini adalah sebanyak 56 konsumen.

\section{Teknik Pengumpulan Data}

Untuk mengumpulkan data serta bahan-bahan yang diperlukan untuk penelitian ini, penulis menggunakan teknik sebagai berikut :

1. Library Research (Penelitian Kepustakaan), yaitu suatu kegiatan untuk mengumpulkan datadata yang berkenaan dengan materi penelitian melalui bahan-bahan bacaan, artikel.

2. Field Work Research (Penelitian Lapangan), yaitu pengamatan langsung terhadap obyek yang akan diteliti, cara ini dapat dilakukan melalui :

a. Angket, adalah pengumpulan data dengan menggunakan suatu daftar pertanyaan tertulis (quisioner) yang diajukan kepada responden yang menjadi unit observasi dalam penelitian.

b. Wawancara, adalah kegiatan untuk mendapatkan data dengan cara mengadakan tanya jawab langsung kepada pihak-pihak yang bersangkutan.

c. Penelitian dokumen, adalah untuk memperoleh data skunder yang berkenaan dengan kelengkapan bahan atau data yang diperlukan untuk penulisan ini.

\section{Metode Analisis}

Rumus yang digunakan penulis dalam memecahkan masalah ini adalah dengan menggunakan metode Regresi Linear Berganda yaitu metode statistik yang digunakan untuk menguji pengaruh dua atau lebih variabel independen terhadap variabel dependen, yang dapat dilihat sebagai berikut :

\footnotetext{
${ }^{1}$ Ibid, Halaman 141.
} 
"Y $=a+b_{1} X_{1}+b_{2} X_{2}+b_{3} X_{3}+\ldots$ $b_{k} X_{k} "$

Keterangan :

$\mathrm{Y}, \mathrm{X}_{1}, \mathrm{X}_{2}, \mathrm{X}_{3}, \ldots \ldots \mathrm{X}_{\mathrm{k}} \quad=$ Variabel-variabel

$\mathrm{a}, \mathrm{b}_{1}, \mathrm{~b}_{2}, \mathrm{~b}_{3}, \ldots \ldots \ldots \mathrm{b}_{\mathrm{k}} \quad=$ Bilangan Konstan (konstanta)

\section{Pengujian Hipotesis}

\subsubsection{Uji F (serentak)}

3.6.2 Perhitungan Koefisien Determinasi $\mathbf{R}^{2}$

3.6.3 Uji t (Uji Parsial)

Pembuktian ini dilakukan pada tingkat signifikansi (a) 5\% atau 0,05, dengan pengujian satu sisi.

Apabila nilai Sig < 0.05, maka Ha diterima dan Ho ditolak.

Apabila nilai Sig > 0.05, maka Ho diterima dan Ha ditolak.

\section{ANALISIS DAN PEMBAHASAN}

\section{Analisis Data Hasil Penelitian}

\section{Variabel Independen Yaitu Dimensi Kualitas (X)}

1. Variabel Performa (X.1.1)

A. Menurut Bapak/Ibu/Saudara/i apakah handphone merek Nokia dapat memberikan kemudahan untuk berkomunikasi?

Tabel V.1 : Tanggapan Responden Mengenai Performa 1

\begin{tabular}{c|l|c|r|r}
\hline No & \multicolumn{1}{|c|}{ Kategori Jawaban } & Skor & Frekuensi & Persentase \\
\hline 1 & Sangat Mudah & 5 & 9 & $16 \%$ \\
\hline 2 & Mudah & 4 & 24 & $43 \%$ \\
\hline 3 & Cukup Mudah & 3 & 23 & $41 \%$ \\
\hline 4 & Kurang Mudah & 2 & 0 & $0 \%$ \\
\hline 5 & Tidak Mudah & 1 & 0 & $0 \%$ \\
\hline \multicolumn{2}{c|}{ Jumlah } & & 56 & $100 \%$ \\
\hline
\end{tabular}

Sumber Data : Data Primer

Berdasarkan tabel di atas, dari 56 responden dapat diketahui bahwa $16 \%$ responden memilih jawaban a, $43 \%$ responden memilih jawaban b, $41 \%$ responden memilih jawaban c, dan tidak ada responden yang memilih jawaban $d$ dan $e$.

B. Menurut Bapak/Ibu/Saudara/i apakah handphone merek Nokia merupakan alat komunikasi yang praktis untuk dibawa kemana-mana?

Tabel V.2 : Tanggapan Responden Mengenai Performa 2 


\begin{tabular}{c|l|c|r|r}
\hline No & \multicolumn{1}{|c|}{ Kategori Jawaban } & Skor & Frekuensi & Persentase \\
\hline 1 & Sangat Praktis & 5 & 10 & $18 \%$ \\
\hline 2 & Praktis & 4 & 15 & $27 \%$ \\
\hline 3 & Cukup Praktis & 3 & 31 & $55 \%$ \\
\hline 4 & Kurang Praktis & 2 & 0 & $0 \%$ \\
\hline 5 & Tidak Praktis & 1 & 0 & $0 \%$ \\
\hline \multicolumn{2}{r|}{ Jumlah } & & 56 & $100 \%$ \\
\hline
\end{tabular}

Sumber Data : Data Primer

Berdasarkan tabel di atas, dari 56 responden dapat diketahui bahwa $18 \%$ responden memilih jawaban a, 27\% responden memilih jawaban b, 55\% responden memilih jawaban c, dan tidak ada responden yang memilih jawaban $\mathrm{d}$ dan e.

2. Variabel Keistimewaan (X.1.2)

A. Menurut Bapak/Ibu/Saudara/i bagaimanakah kemudahan penggunaan fitur yang ada pada handphone merek Nokia?

Tabel V.3 : Tanggapan Responden Mengenai Keistimewaan 1

\begin{tabular}{c|l|c|r|r}
\hline No & \multicolumn{1}{|c|}{ Kategori Jawaban } & Skor & Frekuensi & Persentase \\
\hline 1 & Sangat Mudah & 5 & 12 & $21 \%$ \\
\hline 2 & Mudah & 4 & 25 & $45 \%$ \\
\hline 3 & Cukup Mudah & 3 & 19 & $34 \%$ \\
\hline 4 & Kurang Mudah & 2 & 0 & $0 \%$ \\
\hline 5 & Tidak Mudah & 1 & 0 & $0 \%$ \\
\hline \multicolumn{2}{c}{ Jumlah } & 56 & $100 \%$ \\
\hline
\end{tabular}

Sumber Data : Data Primer

Berdasarkan tabel di atas, dari 56 responden dapat diketahui bahwa $21 \%$ responden memilih jawaban a, 45\% responden memilih jawaban b, 34\% responden memilih jawaban c, dan tidak ada responden yang memilih jawaban $d$ dan e.

B. Menurut Bapak/Ibu/Saudara/i bagaimanakah perkembangan fitur yang digunakan pada handphone merek Nokia?

Tabel V.4 : Tanggapan Responden Mengenai Keistimewaan 2

\begin{tabular}{c|l|c|r|r}
\hline No & \multicolumn{1}{|c|}{ Kategori Jawaban } & Skor & Frekuensi & Persentase \\
\hline 1 & Sangat Berkembang & 5 & 10 & $18 \%$ \\
\hline 2 & Berkembang & 4 & 22 & $39 \%$ \\
\hline 3 & Cukup Berkembang & 3 & 24 & $43 \%$ \\
\hline
\end{tabular}




\begin{tabular}{r|l|r|r|r}
\hline 4 & Kurang Berkembang & 2 & 0 & $0 \%$ \\
\hline 5 & Tidak Berkembang & 1 & 0 & $0 \%$ \\
\hline \multicolumn{2}{c|}{ Jumlah } & 56 & $100 \%$ \\
\hline
\end{tabular}

Sumber Data : Data Primer

Berdasarkan tabel di atas, dari 56 responden dapat diketahui bahwa $18 \%$ responden memilih jawaban a, 39\% responden memilih jawaban b, $43 \%$ responden memilih jawaban c, dan tidak ada responden yang memilih jawaban d dan e.

3. Variabel Keandalan $(\mathrm{X} \cdot 1.3)$

A. Menurut Bapak/Ibu/Saudara/i bagaimanakah kemampuan handphone merek Nokia dalam menerima sinyal ?

Tabel V.5 : Tanggapan Responden Mengenai Keandalan 1

\begin{tabular}{c|l|c|r|r}
\hline No & Kategori Jawaban & Skor & Frekuensi & Persentase \\
\hline 1 & Sangat Kuat & 5 & 9 & $16 \%$ \\
\hline 2 & Kuat & 4 & 20 & $36 \%$ \\
\hline 3 & Cukup Kuat & 3 & 26 & $46 \%$ \\
\hline 4 & Kurang Kuat & 2 & 1 & $2 \%$ \\
\hline 5 & Tidak Kuat & 1 & 0 & $0 \%$ \\
\hline \multicolumn{2}{c|}{ Jumlah } & 56 & $100 \%$ \\
\hline
\end{tabular}

Sumber Data : Data Primer

Berdasarkan tabel di atas, dari 56 responden dapat diketahui bahwa 16\% responden memilih jawaban a, 36\% responden memilih jawaban b, $46 \%$ responden memilih jawaban c, $2 \%$ responden memilih jawaban d, dan tidak ada responden yang memilih jawaban e.

B. Menurut Bapak/Ibu/Saudara/i bagaimanakah kemampuan handphone merek Nokia dalam mengirimkan sinyal ?

Tabel V.6 : Tanggapan Responden Mengenai Keandalan 2

\begin{tabular}{c|l|c|r|r}
\hline No & Kategori Jawaban & Skor & Frekuensi & Persentase \\
\hline 1 & Sangat Kuat & 5 & 10 & $18 \%$ \\
\hline 2 & Kuat & 4 & 22 & $39 \%$ \\
\hline 3 & Cukup Kuat & 3 & 24 & $43 \%$ \\
\hline 4 & Kurang Kuat & 2 & 0 & $0 \%$ \\
\hline 5 & Tidak Kuat & 1 & 0 & $0 \%$ \\
\hline \multicolumn{2}{c|}{ Jumlah } & & 56 & $100 \%$ \\
\hline
\end{tabular}

Sumber Data : Data Primer 
Berdasarkan tabel di atas, dari 56 responden dapat diketahui bahwa $18 \%$ responden memilih jawaban a, 39\% responden memilih jawaban b, $43 \%$ responden memilih jawaban c, dan tidak ada responden yang memilih jawaban d dan e.

4. Variabel Konformansi (X.1.4)

A. Menurut Bapak/Ibu/Saudara/i bagaimanakah perkembangan spesifikasi dari handphone merek Nokia?

Tabel V.7 : Tanggapan Responden Mengenai Konformansi 1

\begin{tabular}{c|l|c|r|r}
\hline No & Kategori Jawaban & Skor & Frekuensi & Persentase \\
\hline 1 & Sangat Baik & 5 & 11 & $20 \%$ \\
\hline 2 & Baik & 4 & 23 & $41 \%$ \\
\hline 3 & Cukup Baik & 3 & 22 & $39 \%$ \\
\hline 4 & Kurang Baik & 2 & 0 & $0 \%$ \\
\hline 5 & Tidak Baik & 1 & 0 & $0 \%$ \\
\hline \multicolumn{2}{c|}{ Jumlah } & & 56 & $100 \%$ \\
\hline
\end{tabular}

Sumber Data : Data Primer

Berdasarkan tabel di atas, dari 56 responden dapat diketahui bahwa 20\% responden memilih jawaban a, $41 \%$ responden memilih jawaban b, 39\% responden memilih jawaban c, dan tidak ada responden yang memilih jawaban $d$ dan $e$.

B. Menurut Bapak/Ibu/Saudara/i apakah spesifikasi handphone merek Nokia yang telah ditetapkan sesuai dengan kebutuhan konsumen?

Tabel V.8 : Tanggapan Responden Mengenai Konformansi 2

\begin{tabular}{c|l|c|r|r}
\hline No & \multicolumn{1}{|c|}{ Kategori Jawaban } & Skor & Frekuensi & Persentase \\
\hline 1 & Sangat Sesuai & 5 & 8 & $14 \%$ \\
\hline 2 & Sesuai & 4 & 20 & $36 \%$ \\
\hline 3 & Cukup Sesuai & 3 & 28 & $50 \%$ \\
\hline 4 & Kurang Sesuai & 2 & 0 & $0 \%$ \\
\hline 5 & Tidak Sesuai & 1 & 0 & $0 \%$ \\
\hline \multicolumn{2}{c|}{ Jumlah } & 56 & $100 \%$ \\
\hline
\end{tabular}

Sumber Data : Data Primer

Berdasarkan tabel di atas, dari 56 responden dapat diketahui bahwa $14 \%$ responden memilih jawaban a, 36\% responden memilih jawaban b, 50\% responden memilih jawaban c, dan tidak ada responden yang memilih jawaban $d$ dan $e$.

5. Variabel Daya Tahan $(\mathrm{X} .1 .5)$

A. Menurut Bapak/Ibu/Saudara/i bagaimanakah daya tahan dari handphone merek Nokia ? 
Tabel V.9: Tanggapan Responden Mengenai Daya Tahan 1

\begin{tabular}{c|l|c|r|r}
\hline No & \multicolumn{1}{|c|}{ Kategori Jawaban } & Skor & \multicolumn{1}{c|}{ Frekuensi } & Persentase \\
\hline 1 & Sangat Kuat & 5 & 8 & $14 \%$ \\
\hline 2 & Kuat & 4 & 28 & $50 \%$ \\
\hline 3 & Cukup Kuat & 3 & 18 & $32 \%$ \\
\hline 4 & Kurang Kuat & 2 & 2 & $4 \%$ \\
\hline 5 & Tidak Kuat & 1 & 0 & $0 \%$ \\
\hline \multicolumn{2}{c|}{ Jumlah } & 56 & $100 \%$ \\
\hline
\end{tabular}

Sumber Data : Data Primer

Berdasarkan tabel di atas, dari 56 responden dapat diketahui bahwa 14\% responden memilih jawaban a, 50\% responden memilih jawaban b, 32\% responden memilih jawaban c, $4 \%$ responden memilih jawaban d, dan tidak ada responden yang memilih jawaban e.

B. Menurut Bapak/Ibu/Saudara/i bagaimanakah ukuran masa pakai dari handphone merek Nokia ?

Tabel V.10 : Tanggapan Responden Mengenai Daya Tahan 2

\begin{tabular}{c|l|c|r|r}
\hline No & Kategori Jawaban & Skor & Frekuensi & Persentase \\
\hline 1 & Sangat Lama & 5 & 9 & $16 \%$ \\
\hline 2 & Lama & 4 & 20 & $36 \%$ \\
\hline 3 & Cukup Lama & 3 & 27 & $48 \%$ \\
\hline 4 & Kurang Lama & 2 & 0 & $0 \%$ \\
\hline 5 & Tidak Lama & 1 & 0 & $0 \%$ \\
\hline \multicolumn{2}{c|}{ Jumlah } & & 56 & $100 \%$ \\
\hline
\end{tabular}

Sumber Data : Data Primer

Berdasarkan tabel di atas, dari 56 responden dapat diketahui bahwa 16\% responden memilih jawaban a, 36\% responden memilih jawaban b, $48 \%$ responden memilih jawaban c, dan tidak ada responden yang memilih jawaban $d$ dan $e$.

6. Variabel Estetika (X.1.6)

A. Menurut Bapak/Ibu/Saudara/i bagaimanakah desain dan unsur warna dari handphone merek nokia?

Tabel V.11 : Tanggapan Responden Mengenai Estetika 1

\begin{tabular}{c|l|c|r|r}
\hline No & \multicolumn{1}{|c|}{ Kategori Jawaban } & Skor & Frekuensi & Persentase \\
\hline 1 & Sangat Menarik & 5 & 12 & $21 \%$ \\
\hline 2 & Menarik & 4 & 29 & $52 \%$ \\
\hline
\end{tabular}




\begin{tabular}{r|l|r|r|r}
\hline 3 & Cukup Menarik & 3 & 15 & $27 \%$ \\
\hline 4 & Kurang Menarik & 2 & 0 & $0 \%$ \\
\hline 5 & Tidak Menarik & 1 & 0 & $0 \%$ \\
\hline \multicolumn{2}{c|}{ Jumlah } & 56 & $100 \%$ \\
\hline
\end{tabular}

Sumber Data : Data Primer

Berdasarkan tabel di atas, dari 56 responden dapat diketahui bahwa $21 \%$ responden memilih jawaban a, $52 \%$ responden memilih jawaban b, $27 \%$ responden memilih jawaban c, dan tidak ada responden yang memilih jawaban $d$ dan e.

B. Menurut Bapak/Ibu/Saudara/i bagaimanakah kualitas suara dari handphone merek Nokia ?

Tabel V.12 : Tanggapan Responden Mengenai Estetika 2

\begin{tabular}{c|l|c|r|r}
\hline No & \multicolumn{1}{|c|}{ Kategori Jawaban } & Skor & Frekuensi & Persentase \\
\hline 1 & Sangat Baik & 5 & 11 & $20 \%$ \\
\hline 2 & Baik & 4 & 31 & $55 \%$ \\
\hline 3 & Cukup Baik & 3 & 14 & $25 \%$ \\
\hline 4 & Kurang Baik & 2 & 0 & $0 \%$ \\
\hline 5 & Tidak Baik & 1 & 0 & $0 \%$ \\
\hline \multicolumn{2}{c|}{ Jumlah } & 56 & $100 \%$ \\
\hline
\end{tabular}

Sumber Data : Data Primer

Berdasarkan tabel di atas, dari 56 responden dapat diketahui bahwa 20\% responden memilih jawaban a, 55\% responden memilih jawaban b, 25\% responden memilih jawaban c, dan tidak ada responden yang memilih jawaban d dan e.

7. Variabel Kualitas Yang Dipersepsikan (X.1.7)

A. Menurut Bapak/Ibu/Saudara/i apakah anda merasa puas selama menggunakan Handphone merek Nokia?

Tabel V.13: Tanggapan Responden Mengenai Kualitas Yang Dipersepsikan 1

\begin{tabular}{c|l|c|r|r}
\hline No & \multicolumn{1}{|c|}{ Kategori Jawaban } & Skor & Frekuensi & Persentase \\
\hline 1 & Sangat Puas & 5 & 11 & $20 \%$ \\
\hline 2 & Puas & 4 & 28 & $50 \%$ \\
\hline 3 & Cukup Puas & 3 & 17 & $30 \%$ \\
\hline 4 & Kurang Puas & 2 & 0 & $0 \%$ \\
\hline 5 & Tidak Puas & 1 & 0 & $0 \%$ \\
\hline \multicolumn{2}{c|}{ Jumlah } & 56 & $100 \%$ \\
\hline
\end{tabular}

Sumber Data : Data Primer 
Berdasarkan tabel di atas, dari 56 responden dapat diketahui bahwa $20 \%$ responden memilih jawaban a, 50\% responden memilih jawaban b, 30\% responden memilih jawaban c, dan tidak ada responden yang memilih jawaban $d$ dan e.

B. Menurut Bapak/Ibu/Saudara/i bagaimanakah reputasi handphone merek Nokia hingga saat ini?

Tabel V.14 : Tanggapan Responden Mengenai Kualitas Yang Dipersepsikan 2

\begin{tabular}{|c|c|c|c|c|}
\hline No & Kategori Jawaban & Skor & Frekuensi & Persentase \\
\hline 1 & Sangat Baik & 5 & 8 & $14 \%$ \\
\hline 2 & Baik & 4 & 21 & $38 \%$ \\
\hline 3 & Cukup Baik & 3 & 26 & $46 \%$ \\
\hline 4 & Kurang Baik & 2 & 1 & $2 \%$ \\
\hline 5 & Tidak Baik & 1 & 0 & $0 \%$ \\
\hline \multicolumn{3}{|c|}{ Jumlah } & 56 & $100 \%$ \\
\hline
\end{tabular}

Sumber Data : Data Primer

Berdasarkan tabel di atas, dari 56 responden dapat diketahui bahwa 14\% responden memilih jawaban a, 38\% responden memilih jawaban b, $46 \%$ responden memilih jawaban c, $2 \%$ responden memilih jawaban d, dan tidak ada responden yang memilih jawaban e.

8. $\quad$ Variabel Kemampuan Pelayanan (X.1.8)

A. Menurut Bapak/Ibu/Saudara/i bagaimanakah personal selling yang diberikan pada saat pembelian handphone merek Nokia?

Tabel V.15 : Tanggapan Responden Mengenai Kemampuan Pelayanan 1

\begin{tabular}{c|l|c|r|r}
\hline No & Kategori Jawaban & Skor & Frekuensi & Persentase \\
\hline 1 & Sangat Baik & 5 & 12 & $21 \%$ \\
\hline 2 & Baik & 4 & 28 & $50 \%$ \\
\hline 3 & Cukup Baik & 3 & 16 & $29 \%$ \\
\hline 4 & Kurang Baik & 2 & 0 & $0 \%$ \\
\hline 5 & Tidak Baik & 1 & 0 & $0 \%$ \\
\hline \multicolumn{2}{c|}{ Jumlah } & & 56 & $100 \%$ \\
\hline
\end{tabular}

Sumber Data : Data Primer

Berdasarkan tabel di atas, dari 56 responden dapat diketahui bahwa $21 \%$ responden memilih jawaban a, 50\% responden memilih jawaban b, 29\% responden memilih jawaban c, dan tidak ada responden yang memilih jawaban d dan e.

B. Menurut Bapak/Ibu/Saudara/i bagaimanakah kemudahan mendapatkan service centre (pusat perbaikan) handphone merek Nokia ? 
Tabel V.16 : Tanggapan Responden Mengenai Kemampuan Pelayanan 2

\begin{tabular}{c|l|c|r|r}
\hline No & \multicolumn{1}{|c|}{ Kategori Jawaban } & Skor & Frekuensi & Persentase \\
\hline 1 & Sangat Mudah & 5 & 12 & $21 \%$ \\
\hline 2 & Mudah & 4 & 19 & $34 \%$ \\
\hline 3 & Cukup Mudah & 3 & 25 & $45 \%$ \\
\hline 4 & Kurang Mudah & 2 & 0 & $0 \%$ \\
\hline 5 & Tidak Mudah & 1 & 0 & $0 \%$ \\
\hline \multicolumn{2}{c|}{ Jumlah } & 56 & $100 \%$ \\
\hline
\end{tabular}

Sumber Data : Data Primer

Berdasarkan tabel di atas, dari 56 responden dapat diketahui bahwa $21 \%$ responden memilih jawaban a, 34\% responden memilih jawaban b, 45\% responden memilih jawaban c, dan tidak ada responden yang memilih jawaban $d$ dan $e$.

\section{Variabel Dependen Yaitu Keputusan Pembelian (Y)}

A. Menurut Bapak/Ibu/Saudara/i apakah kualitas produk dari Handphone merek Nokia yang meliputi performa, keistimewaan, keandalan, konformansi, daya tahan, estetika, dan kualitas yang dipersepsikan berpengaruh terhadap keputusan pembelian?

Tabel V.17 : Tanggapan Responden Mengenai Keputusan Pembelian 1

\begin{tabular}{c|l|c|r|r}
\hline No & \multicolumn{1}{|c|}{ Kategori Jawaban } & Skor & Frekuensi & Persentase \\
\hline 1 & Sangat Berpengaruh & 5 & 23 & $41 \%$ \\
\hline 2 & Berpengaruh & 4 & 14 & $25 \%$ \\
\hline 3 & Cukup Berpengaruh & 3 & 17 & $30 \%$ \\
\hline 4 & Kurang Berpengaruh & 2 & 2 & $4 \%$ \\
\hline 5 & Tidak Berpengaruh & 1 & 0 & $0 \%$ \\
\hline \multicolumn{2}{c|}{ Jumlah } & & 56 & $100 \%$ \\
\hline
\end{tabular}

Sumber Data : Data Primer

Berdasarkan tabel di atas, dari 56 responden dapat diketahui bahwa $41 \%$ responden memilih jawaban a, 25\% responden memilih jawaban b, 30\% responden memilih jawaban c, $4 \%$ responden memilih jawaban d, dan tidak ada responden yang memilih jawaban e.

B. Menurut Bapak/Ibu/Saudara/i apakah kemampuan pelayanan yang diberikan baik pada saat pembelian maupun pada saat perbaikan berpengaruh terhadap keputusan pembelian?

Tabel V.18 : Tanggapan Responden Mengenai Keputusan Pembelian 2

\begin{tabular}{c|l|c|r|r}
\hline No & \multicolumn{1}{|c|}{ Kategori Jawaban } & Skor & Frekuensi & Persentase \\
\hline 1 & Sangat Berpengaruh & 5 & 12 & $21 \%$ \\
\hline 2 & Berpengaruh & 4 & 19 & $34 \%$ \\
\hline
\end{tabular}




\begin{tabular}{r|l|r|r|r}
\hline 3 & Cukup Berpengaruh & 3 & 20 & $36 \%$ \\
\hline 4 & Kurang Berpengaruh & 2 & 5 & $9 \%$ \\
\hline 5 & Tidak Berpengaruh & 1 & 0 & $0 \%$ \\
\hline \multicolumn{2}{c|}{ Jumlah } & 56 & $100 \%$ \\
\hline
\end{tabular}

Sumber Data : Data Primer

Berdasarkan tabel di atas, dari 56 responden dapat diketahui bahwa $21 \%$ responden memilih jawaban a, 34\% responden memilih jawaban b, 36\% responden memilih jawaban c, 9\% responden memilih jawaban d, dan tidak ada responden yang memilih jawaban e.

Dari seluruh hasil jawaban responden, untuk mempermudah dalam hal pemahaman tulisan ini, maka penulis menyajikan rangkuman tanggapan responden, dalam tabel sebagai berikut :

\section{Analisis Statistik}

Adapun perhitungan yang dilakukan untuk mengetahui pengaruh antara variabel performa $\left(\mathrm{X}_{1.1}\right)$, keistimewaan $\left(\mathrm{X}_{1.2}\right)$, keandalan $\left(\mathrm{X}_{1.3}\right)$, konformansi $\left(\mathrm{X}_{1.4}\right)$, daya tahan $\left(\mathrm{X}_{1.5}\right)$, estetika $\left(\mathrm{X}_{1.6}\right)$, kualitas yang dipersepsikan $\left(\mathrm{X}_{1.7}\right)$, kemampuan pelayanan $\left(\mathrm{X}_{1.8}\right)$ terhadap keputusan pembelian $(\mathrm{Y})$, dibantu dengan program SPSS (Statistical Product Service Solutions) versi 11.5.

\section{Analisis Regresi Linear Berganda}

Sesuai dengan penjelasan pada bab sebelumnya, rumus yang digunakan penulis dalam memecahkan masalah ini adalah metode Regresi Linear Berganda, yaitu sebagai berikut :

"Y $=\mathrm{a}+\mathrm{b}_{1} \mathrm{X}_{1}+\mathrm{b}_{2} \mathrm{X}_{2}+\mathrm{b}_{3} \mathrm{X}_{3}+\ldots \ldots \ldots \ldots \mathrm{b}_{\mathrm{k}} \mathrm{X}_{\mathrm{k}} "$

Keterangan :

$\mathrm{Y}, \mathrm{X}_{1}, \mathrm{X}_{2}, \mathrm{X}_{3}, \ldots \ldots \mathrm{X}_{\mathrm{k}} \quad=$ Variabel-variabel

$\mathrm{a}, \mathrm{b}_{1}, \mathrm{~b}_{2}, \mathrm{~b}_{3}, \ldots \ldots \ldots \mathrm{b}_{\mathrm{k}} \quad=$ Bilangan Konstan (konstanta)

\section{Regression}


Tabel V.20 : Hasil Analisis Regresi Linear Berganda

Coefficients(a)

\begin{tabular}{|c|c|c|c|c|c|c|}
\hline \multirow[t]{2}{*}{$\begin{array}{l}\text { Mod } \\
\text { el }\end{array}$} & & \multicolumn{2}{|c|}{$\begin{array}{c}\text { Unstandardized } \\
\text { Coefficients }\end{array}$} & \multirow{2}{*}{$\begin{array}{c}\text { Standardi } \\
\text { zed } \\
\text { Coefficie } \\
\text { nts } \\
\\
\text { Beta }\end{array}$} & \multirow[t]{2}{*}{$\mathrm{t}$} & \multirow[t]{2}{*}{ Sig. } \\
\hline & & B & $\begin{array}{l}\text { Std. } \\
\text { Error }\end{array}$ & & & \\
\hline \multirow[t]{9}{*}{$\overline{1}$} & (Constant) & -6.224 & 2.287 & & -2.721 & .009 \\
\hline & Performa & .068 & .115 & .074 & .591 & .557 \\
\hline & Keistimewaan & .239 & .137 & .221 & 1.745 & .087 \\
\hline & Keandalan & .133 & .149 & .111 & .895 & .375 \\
\hline & Konformansi & .302 & .142 & .242 & 2.132 & .038 \\
\hline & Daya Tahan & .307 & .144 & .245 & 2.135 & .038 \\
\hline & Estetika & .319 & .126 & .280 & 2.521 & .015 \\
\hline & $\begin{array}{l}\text { Kualitas Yang } \\
\text { Dipersepsikan }\end{array}$ & .261 & .144 & .231 & 1.811 & .077 \\
\hline & $\begin{array}{l}\text { Kemampuan } \\
\text { Pelayanan }\end{array}$ & .210 & .123 & .192 & 1.707 & .094 \\
\hline
\end{tabular}

a Dependent Variable: Keputusan Pembelian

Sumber Data : Data Yang Diolah Dari Data Primer

Dari coefficient dapat diketahui persamaan regresi linear bergandanya sebagai berikut :

$Y=a+b_{1} X_{1}+b_{2} X_{2}+b_{3} X_{3}+\ldots \ldots \ldots \ldots b_{k} X_{k}$

$\mathrm{Y}=-6,224+0,068 \mathrm{x}_{1.1}+0,239 \mathrm{x}_{1.2}+0,133 \mathrm{x}_{1.3}+0,302 \mathrm{x}_{1.4}+0,307 \mathrm{x}_{1.5}$

$+0,319 \mathrm{x}_{1.6}+0,261 \mathrm{x}_{1.7}+0,210 \mathrm{x}_{1.8}$ 
Tabel V.21: Hasil Analisis Koefisien Korelasi

Correlations

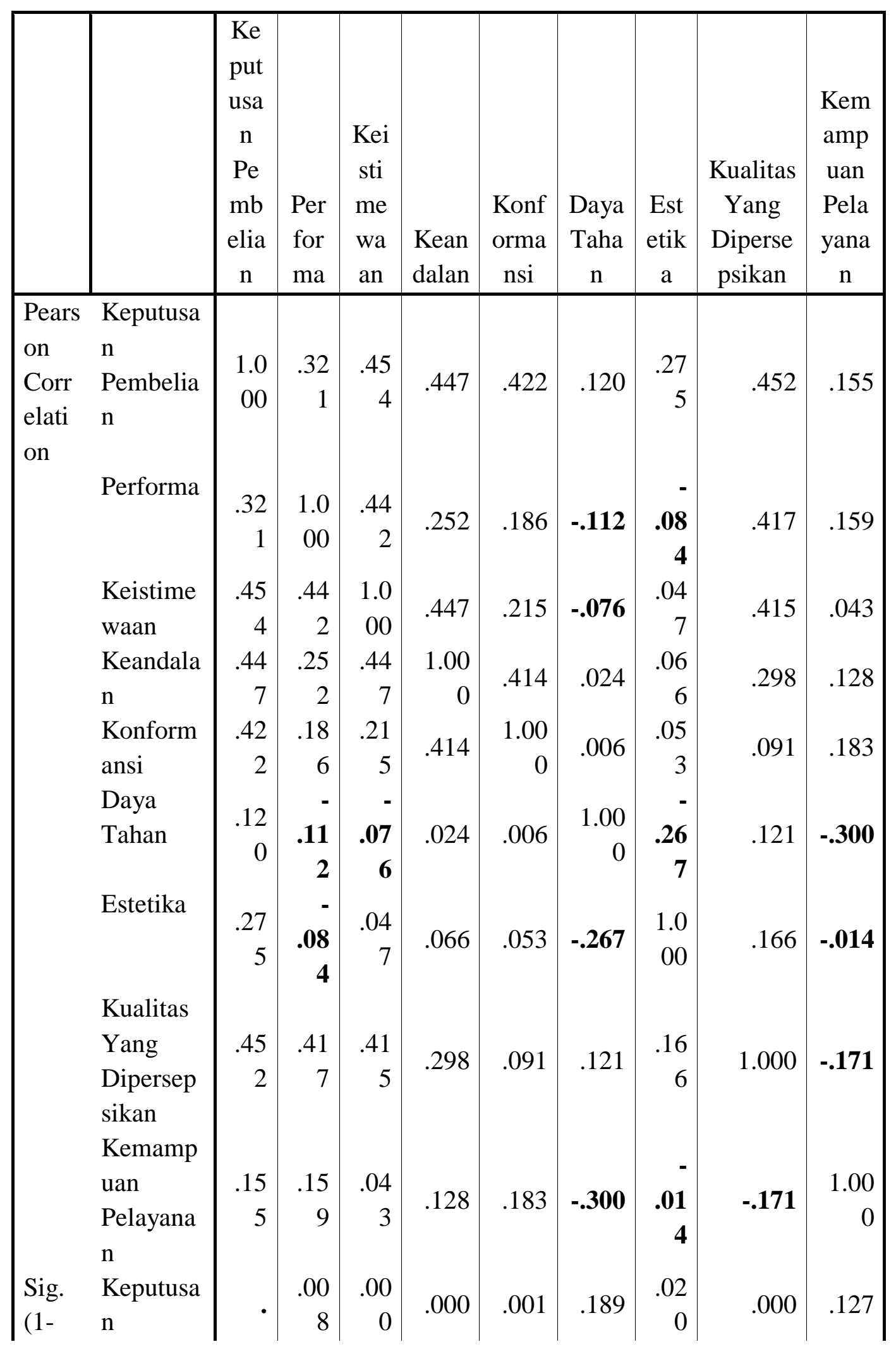




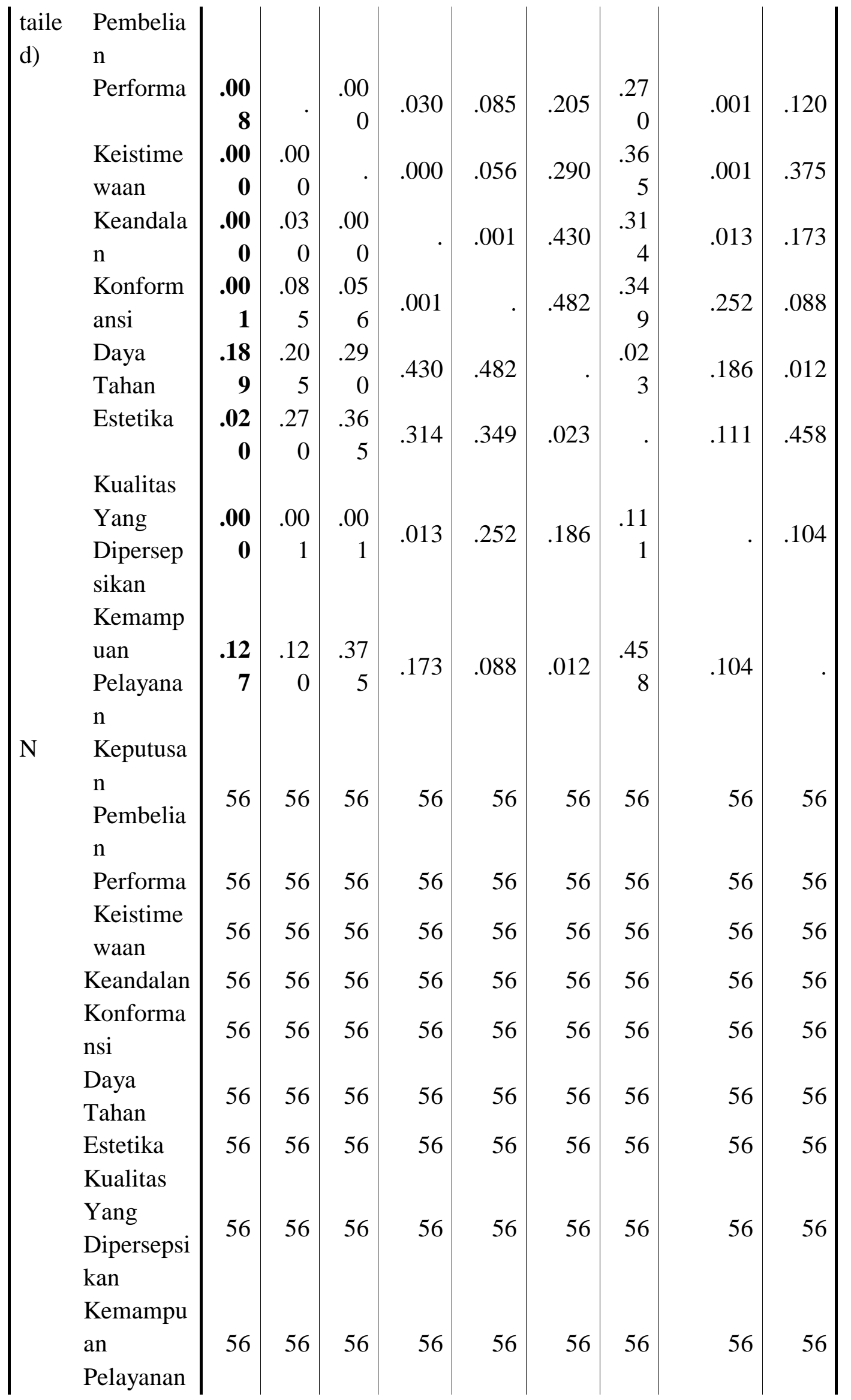


a. Diperoleh nilai Sig. variabel performa dan keputusan pembelian 0,008 $<0,05$, sehingga dapat dikatakan bahwa performa berhubungan signifikan dengan keputusan pembelian. Kondisi ini terjadi apabila handphone praktis sebagai alat komunikasi yang kompatibel, memiliki keistimewaan, keandalanya kuat, serta memiliki spesifikasi yang sesuai dengan keinginan konsumen dan berkembang, adanya persepsi yang baik dari konsumen, serta didukung dengan pelayanan yang baik, walaupun daya tahan handphone tidak kuat, dan tidak memiliki estetika, maka konsumen akan membeli handphone tersebut.

b. Diperoleh nilai Sig. variabel keistimewaan dan keputusan pembelian $0,000<0,05$, sehingga dapat dikatakan bahwa keistimewaan berhubungan signifikan dengan keputusan pembelian.

c. Diperoleh nilai Sig. variabel keandalan dan keputusan pembelian $0,000<0,05$, sehingga dapat dikatakan bahwa keandalan berhubungan signifikan dengan keputusan pembelian.

d. Diperoleh nilai Sig. variabel konformansi dan keputusan pembelian 0,001 <0,05, sehingga dapat dikatakan bahwa konformansi berhubungan signifikan dengan keputusan pembelian.

e. Diperoleh nilai Sig. variabel daya tahan dan keputusan pembelian 0,189>0,05, sehingga dapat dikatakan bahwa daya tahan berhubungan tidak signifikan dengan keputusan pembelian. Kondisi ini terjadi apabila daya tahan handphone kuat, keandalanya kuat, memiliki spesifikasi yang sesuai dengan keinginan konsumen dan berkembang, serta adanya persepsi yang baik dari konsumen tetapi handphone tidak praktis sebagai alat komunikasi yang kompatibel, tidak memiliki keistimewaan dan estetika, serta tidak didukung dengan pelayanan yang baik, maka konsumen tidak akan membeli handphone tersebut.

f. Diperoleh nilai Sig. variabel estetika dan keputusan pembelian $0,020<0,05$, sehingga dapat dikatakan bahwa estetika berhubungan signifikan dengan keputusan pembelian.

g. Diperoleh nilai Sig. variabel kualitas yang dipersepsikan dan keputusan pembelian 0,000<0,05, sehingga dapat dikatakan bahwa kualitas yang dipersepsikan berhubungan signifikan dengan keputusan pembelian.

h. Diperoleh nilai Sig. Variabel kemampuan pelayanan dan keputusan pembelian 0,127 > 0,05, sehingga dapat dikatakan bahwa kemampuan pelayanan berhubungan tidak signifikan dengan keputusan pembelian. Kondisi ini terjadi apabila adanya pelayanan yang baik, handphone praktis sebagai alat komunikasi yang kompatibel, memiliki keistimewaan, keandalanya kuat, serta memiliki spesifikasi yang sesuai dengan keinginan konsumen dan berkembang, tetapi daya tahan handphone tidak kuat, tidak memiliki estetika, serta adanya persepsi yang tidak baik dari konsumen, maka konsumen tidak akan membeli handphone tersebut.

Tabel V.22 : Variabel Entered / Removed (b) 
Variables Entered/Removed(b)

\begin{tabular}{l|r|r|r}
\hline Model & Variables Entered & Variables Removed & Method \\
\hline 1 & Kemampuan Pelayanan, & & \\
Estetika, Keistimewaan, & & Enter \\
& Konformansi, Daya Tahan, \\
& $\begin{array}{r}\text { Performa, Keandalan, Kualitas } \\
\text { Yang Dipersepsikan(a) }\end{array}$ & & \\
& & \\
\hline
\end{tabular}

a All requested variables entered.

b Dependent Variable: Keputusan Pembelian

Sumber Data : Data Yang Diolah Dari Data Primer

Tabel variable entered menunjukkan bahwa tidak ada variabel yang dikeluarkan (removed) atau dengan kata lain kedelapan variabel bebas dimasukkan dalam perhitungan regresi

\section{Pembahasan Hasil Penelitian dan Pengujian Hipotesis}

\section{Uji F}

Uji secara serentak terhadap variabel independen kepada variabel dependen, hal ini dilakukan untuk mengetahui pengaruh variabel independen terhadap variabel dependen secara menyeluruh

Tabel V.23 : Hasil Uji F

$\operatorname{ANOVA}(\mathbf{b})$

\begin{tabular}{|c|c|c|c|c|c|c|}
\hline Model & & $\begin{array}{l}\text { Sum of } \\
\text { Squares }\end{array}$ & $\mathrm{df}$ & $\begin{array}{c}\text { Mean } \\
\text { Square }\end{array}$ & $\mathrm{F}$ & Sig. \\
\hline \multirow[t]{3}{*}{1} & $\begin{array}{l}\text { Regressio } \\
n\end{array}$ & 36.898 & 8 & \multirow{3}{*}{$\begin{array}{r}4.612 \\
.735\end{array}$} & \multirow[t]{3}{*}{6.278} & \multirow[t]{3}{*}{$.000(a)$} \\
\hline & Residual & 34.531 & 47 & & & \\
\hline & Total & 71.429 & 55 & & & \\
\hline
\end{tabular}

a Predictors: (Constant), Kemampuan Pelayanan, Estetika, Keistimewaan, Konformansi, Daya Tahan, Performa, Keandalan, Kualitas Yang Dipersepsikan

b Dependent Variable: Keputusan Pembelian

Sumber Data : Data Yang Diolah Dari Data Primer 


\subsubsection{Perhitungan Koefisien Determinasi $R^{2}$}

Koefisien determinasi digunakan untuk mengetahui kuatnya pengaruh antara variabel independen terhadap variabel dependen.

Tabel V.24: Hasil Uji Koefisien Determinasi $\mathrm{R}^{2}$

Model Summary

\begin{tabular}{|c|c|c|c|c|c|c|c|c|c|}
\hline $\begin{array}{l}\mathrm{M} \\
\text { od } \\
\text { el }\end{array}$ & \multirow[t]{2}{*}{$\mathrm{R}$} & \multirow[t]{2}{*}{$\begin{array}{c}\mathrm{R} \\
\text { Squa } \\
\text { re }\end{array}$} & \multirow[t]{2}{*}{$\begin{array}{l}\text { Adjuste } \\
\text { d R } \\
\text { Square }\end{array}$} & \multirow[t]{2}{*}{$\begin{array}{l}\text { Std. Error of } \\
\text { the Estimate }\end{array}$} & \multicolumn{5}{|c|}{ Change Statistics } \\
\hline & & & & & $\begin{array}{l}\text { R Square } \\
\text { Change }\end{array}$ & $\begin{array}{c}\text { F } \\
\text { Chan } \\
\text { ge }\end{array}$ & $\begin{array}{c}\mathrm{df} \\
1\end{array}$ & $\begin{array}{c}\mathrm{df} \\
2\end{array}$ & $\begin{array}{c}\text { Sig. } \\
\text { F } \\
\text { Chan } \\
\text { ge }\end{array}$ \\
\hline 1 & $\begin{array}{r}.719(\mathrm{a} \\
)\end{array}$ & .517 & .434 & .85715 & .517 & $\begin{array}{r}6.27 \\
8\end{array}$ & 8 & 47 & .000 \\
\hline
\end{tabular}

a Predictors: (Constant), Kemampuan Pelayanan, Estetika, Keistimewaan, Konformansi,

Daya Tahan, Performa, Keandalan, Kualitas Yang Dipersepsikan

Sumber Data : Data Yang Diolah Dari Data Primer

Koefisien determinasi adalah sebesar 0,434. Karena jumlah variabel independen dalam penelitian ini lebih dari dua maka yang digunakan adalah nilai dari Adjusted $\mathrm{R}$ Square. Adjusted $\mathrm{R}^{2}$ adalah 0,434 hal ini berarti sekitar 43,4\% keputusan pembelian dapat dijelaskan oleh variabel performa $\left(\mathrm{X}_{1.1}\right)$, keistimewaan $\left(\mathrm{X}_{1.2}\right)$, keandalan $\left(\mathrm{X}_{1.3}\right)$, konformansi $\left(\mathrm{X}_{1.4}\right)$, daya tahan $\left(\mathrm{X}_{1.5}\right)$, estetika $\left(\mathrm{X}_{1.6}\right)$, kualitas yang dipersepsikan $\left(\mathrm{X}_{1.7}\right)$, kemampuan pelayanan $\left(\mathrm{X}_{1.8}\right)$, dan sisanya ( $100 \%$ $-43,4 \%=56,6 \%)$ dijelaskan oleh variabel-variabel lain yang tidak dimasukkan dalam penelitian ini.

\section{Uji t (uji parsial)}

Apabila nilai Sig < 0.05 , maka Ha diterima dan Ho ditolak yang artinya terdapat pengaruh antara variabel independen dan variabel dependen yang signifikan, sedangkan apabila Sig > 0.05 maka Ho diterima dan Ha ditolak yang artinya tidak terdapat pengaruh yang signifikan antara variabel independen dan variabel dependen.

Tabel V.25 : Hasil Uji t

\begin{tabular}{c|l|c|c}
\hline No & \multicolumn{1}{|c|}{ Variabel } & Sig & a \\
\hline 1 & Performa $\left(\mathrm{X}_{1.1}\right)$ & 0,557 & 0,05 \\
\hline 2 & Keistimewaan $\left(\mathrm{X}_{1.2}\right)$ & 0,087 & 0,05 \\
\hline 3 & Keandalan $\left(\mathrm{X}_{1.3}\right)$ & 0,375 & 0,05 \\
\hline
\end{tabular}




\begin{tabular}{l|l|r|l}
\hline 4 & Konformansi $\left(\mathrm{X}_{1.4}\right)$ & 0,038 & 0,05 \\
\hline 5 & Daya Tahan $\left(\mathrm{X}_{1.5}\right)$ & 0,038 & 0,05 \\
\hline 6 & Estetika $\left(\mathrm{X}_{1.6}\right)$ & 0,015 & 0,05 \\
\hline 7 & Kualitas Yang Dipersepsikan $\left(\mathrm{X}_{1.7}\right)$ & 0,077 & 0,05 \\
\hline 8 & Kemampuan Pelayanan $\left(\mathrm{X}_{1.8}\right)$ & 0,094 & 0,05 \\
\hline
\end{tabular}

Sumber Data : Data Yang Diolah Dari Data Primer

\section{KESIMPULAN DAN SARAN \\ Kesimpulan}

Berdasarkan hasil uji f, maka dapat ditarik kesimpulan bahwa secara serentak variabel dimensi kualitas berpengaruh signifikan terhadap keputusan pembelian handphone merek Nokia pada Sentral Phone Samarinda., sedangkan hasil uji koefisien determinasi $\mathrm{R}^{2}$, maka dapat ditarik kesimpulan bahwa nilai $\mathrm{R}^{2}$ sebesar $43,4 \%$. Berarti keputusan pembelian handphone merek Nokia pada Sentral Phone Samarinda dipengaruhi oleh variabel dimensi kualitas sebesar 43,4\%. dan sisa nilai sebesar 56,6\% merupakan pengaruh dari variabel lain yang tidak diteliti yang juga berpengaruh terhadap keputusan pembelian handphone merek Nokia pada Sentral Phone Samarinda.. Hasil uji t, bahwa dari delapan indikator yang digunakan untuk mengukur variabel dimensi kualitas, terdapat lima indikator yang berpengaruh tidak signifikan terhadap keputusan pembelian, yaitu variabel performa, keistimewaan, keandalan, kualitas yang dipersepsikan, kemampuan pelayanan. Dan terdapat tiga indikator yang berpengaruh signifikan terhadap keputusan pembelian, yaitu variabel konformansi, daya tahan, estetika.

\section{Saran}

Bagi perusahaan yang berorientasi pada konsumen (pasar) maka kegiatan pemasaran akan bermula dan berakhir pada konsumen, artinya dimulai dari menentukan apa yang diinginkan konsumen dan diakhiri dengan kepuasan konsumen. Karena pemuasan kebutuhan konsumen merupakan syarat mutlak bagi kelangsungan hidup perusahaan, agar perusahaan dapat bertahan dan berkembang. Dengan adanya hubungan yang saling mempengaruhi antara variabel dimensi kualitas dengan variabel keputusan pembelian, maka pimpinan dan pihak manajemen Sentral Phone Samarinda perlu memahami perilaku konsumen (consumer behavior) terhadap handphone atau merek handphone, karena konsumen berasal dari beberapa segmen dan keinginan konsumen selalu berubah dari waktu ke waktu, sehingga apa yang diingikan dan dibutuhkan juga berbeda. 


\section{DAFTAR PUSTAKA}

A. Shimp Terence, 2004, Periklanan \& Promosi : Aspek Tambahan Komunikasi Pemasaran Terpadu, Edisi kelima, Erlangga, Jakarta.

Assauri Sofjan, 2004, Manajemen Pemasaran, Edisi pertama, PT. Raja Grafindo Persada, Jakarta.

Kotler Philip, 2012, Manajemen Pemasaran, Edisi milenium, PT. Prenhallindo, Jakarta.

M.N. Nasution, 2005, Manajemen Mutu Terpadu, Edisi kedua, Ghalia Indonesia, Bogor.

Prawirosentono Suyadi, 2004, Filosofi Baru Tentang Manajemen Mutu Terpadu Total Quality Manajemen Abad 21 Studi kasus dan analisis, edisi pertama, PT. Bumi Aksara, Jakarta.

Ruslan Rosady, 2003, Metode Penelitian : Public Relations \& Komunikasi, Edisi pertama, PT. Raja Grafindo Persada, Jakarta.

Sutisna, 2010, Perilaku Konsumen \& Komunikasi Pemasaran, Edisi pertama, PT. Remaja Rosdakarya.

Swastha Basu, Irawan, 2015, Manajemen Pemasaran Modern, Edisi kedua, Liberty Offset, Yogyakarta.

Tjiptono Fandy, Anastasia Diana, 2001, Total Quality Manajemen, Edisi revisi, ANDI, Yogyakarta. 